\title{
Cholinergic Inhibition of Short (Outer) Hair Cells of the Chick's Cochlea
}

\author{
P. A. Fuchs and B. W. Murrow \\ Department of Physiology, University of Colorado School of Medicine, Denver, Colorado 80262
}

\begin{abstract}
Cochlear hair cells are thought to be inhibited by the release of ACh from efferent neurons. Several studies have implicated $\mathrm{Ca}^{2+}$ as a postsynaptic intermediary in hair cell inhibition, but its role remains unproven. We have made wholecell, tight-seal recordings from single short hair cells (the avian analog of outer hair cells in the mammalian cochlea), isolated from the chick's cochlea, to determine the mechanism of cholinergic inhibition. These cells hyperpolarized upon exposure to $\mathrm{ACh}$, although a brief depolarization preceded the much larger, longer-lasting hyperpolarization. In voltage clamp ACh evoked an outward current that reversed in sign near the $\mathrm{K}^{+}$equilibrium potential. A small, transient inward current preceded the predominant outward current. The ACh-evoked $\mathrm{K}^{+}$current depended on $\mathrm{Ca}^{2+}$ in the external saline, or could be prevented when the cell was dialyzed with the rapid $\mathrm{Ca}^{2+}$ buffer BAPTA. In BAPTA-loaded cells a residual inward current was seen. This activated with very little delay upon exposure of the cell to $\mathrm{ACh}$ and reversed near $0 \mathrm{mV}$ membrane potential. Thus, the hair cell ACh receptor appears to be a nonspecific cation channel through which $\mathrm{Ca}^{2+}$ enters and triggers the opening of nearby $\mathrm{Ca}^{2+}$-activated $\mathrm{K}^{+}$channels. However, the ACh-evoked $\mathrm{K}^{+}$ channels are not the same as the "maxi" $K^{+}$channels activated by $\mathrm{Ca}^{2+}$ influx through voltage-gated $\mathrm{Ca}^{2+}$ channels in these same cells.
\end{abstract}

Cholinergic synapses have long been defined as either nicotinic or muscarinic based on their pharmacology (Dale, 1914), and each receptor type produces quite different postsynaptic effects. Nicotinic receptors are ligand-gated cation channels, usually mediating excitation as in skeletal muscle. Muscarinic receptors interact with G-proteins to produce longer-lasting changes in excitability, as exemplified by inhibition of heart muscle. Inhibition of cochlear hair cells appears to involve a cholinergic receptor and postsynaptic mechanism that differs substantially from both of these.

Efferent axons make direct synaptic contact with outer hair cells in the cochleas of mammals and birds. When activated, these axons inhibit cochlear afferent activity (Galambos, 1956; Fex, 1962) by releasing $\mathrm{ACh}$ onto outer hair cells (reviewed by

\footnotetext{
Received Aug. 9, 1991; revised Oct. 8, 1991; accepted Oct. 10, 1991.

We acknowledge Drs. W. J. Betz, A. I. McNiven, and most especially A. R. Martin for enthusiastic discussion and careful critique of the manuscript. We thank Mr. G. Tarver for his expert draftsmanship. This work was supported by NIDCD Grant DC00276 and by NIH Training Grant NS07083.

Correspondence should be addressed to P. A. Fuchs, Physiology Department, C240, University of Colorado School of Medicine, 4200 East 9th Avenue, Denver, $\mathrm{CO} 80262$.

Copyright (C) 1992 Society for Neuroscience $0270-6474 / 92 / 120800-10 \$ 05.00 / 0$
}

Klinke, 1981). Microelectrode studies from the turtle showed that hair cells are hyperpolarized during efferent inhibition, and by application of exogenous ACh, possibly by activation of a $\mathrm{K}^{+}$current (Art et al., 1982, 1984, 1985). Similarly, the cholinergic agonist carbachol activates a $\mathrm{K}^{+}$current in short (outer) hair cells (SHCs) of the chick's cochlea (Murrow and Fuchs, 1990a). Thus, inhibition of hair cells might appear similar to muscarinic inhibition as in the heart and result in a $\mathrm{K}^{+}$conductance increase through second messenger pathways. However, the pharmacology of cochlear inhibition has resisted such classification, and some findings suggest that a nicotinic cholinergic receptor might serve this inhibition. This includes the observation that $\alpha$-bungarotoxin, a normally irreversible blocker at the neuromuscular junction, blocks cochlear inhibition reversibly (Fex and Adams, 1978). Also, the inhibitory potentials produced by efferent activity in turtle hair cells and the carbachol-activated $\mathrm{K}^{+}$currents in chick cells are relatively rapid compared to known muscarinic effects.

These observations suggest that inhibition of cochlear hair cells may occur by way of a previously unidentified cholinergic mechanism. Here we report experiments in which whole-cell, tight-seal recordings from isolated SHCs of the chick's cochlea show that ACh acts to open a channel not unlike the nicotinic receptor of muscle and nerve. This nonspecific cation channel permits $\mathrm{Ca}^{2+}$ influx, which in turn activates a much larger $\mathrm{Ca}^{2+}$ dependent $\mathrm{K}^{+}$current and so hyperpolarizes the cell. The underlying $\mathrm{K}^{+}$channels are probably not the "maxi" $\mathrm{K}^{+}$channels activated by voltage-gated $\mathrm{Ca}^{2+}$ influx in these same cells (Fuchs and Evans, 1990), but rather a separate class of $\mathrm{Ca}^{2+}$-activated $\mathrm{K}^{+}$channel that subserves cholinergic inhibition. The surprising conclusion is that activation of a normally excitatory channel type-a nicotinic(-like) cholinergic receptor-results in inhibition of hair cells as a consequence of associated postsynaptic specializations. This mechanism of action, in combination with the unusual pharmacological profile of this receptor (Fuchs and Murrow, 1991), demonstrates that cholinergic inhibition of cochlear hair cells proceeds by way of a postsynaptic mechanism and receptor type that have not been described previously, and may represent a novel class of inhibitory interactions.

Some of these results have appeared in abstract (Murrow and Fuchs, 1990b; Fuchs and Murrow, 1991).

\section{Materials and Methods}

Chick hatchlings (Gallus domesticus Leghorn, 10-21 d old) were decapitated, and the cochlear duct was removed from the sagittally sectioned cranium in ice-cold, oxygenated saline. Hair cells were isolated from the chick's cochlea and subjected to whole-cell, tight-seal recording using procedures that have been described previously (Fuchs et al., 1988; Fuchs and Evans, 1990). Series resistance during these recordings ranged 
from 4 to $9 \mathrm{M} \Omega$ and was $90 \%$ compensated with the patch-clamp amplifier. The average input capacitance of the cells was $7 \mathrm{pF}$, yielding clamp time constants of 28-63 $\mu \mathrm{sec}$. Prior to recording, the length and apical surface diameter of each cell were measured using Hoffman optics on a Nikon inverted microscope. Short hair cells were identified as having apical surface diameters greater than their length (Tanaka and Smith, 1978; Murrow and Fuchs, 1990a).

Hair cells were positioned on the bottom of a $35 \mathrm{~mm}$ tissue culture dish that was slowly perfused with oxygenated saline. Two different methods were used to apply $\mathrm{ACh}$ (Fig. $1 \mathrm{~A}$ ). In one, an array of glass tubes ( $200 \mu \mathrm{m}$ openings) was mounted on a manipulator and positioned near the cell. Each tube was connected to a reservoir filled with an experimental solution, and flow from it was regulated by a stopcock. It was possible to block $\mathrm{K}^{+}$currents within $100 \mathrm{msec}$ when such a system was used to superfuse tetraethylammonium (TEA) (Fuchs et al., 1988). ACh $(100 \mu \mathrm{M})$ in standard chick saline or $\mathrm{Ca}^{2+}$-free saline was applied to cells in this way. However, in the majority of the experiments 100 $\mu \mathrm{M} \mathrm{ACh}$ in standard chick saline was pressure ejected (approximately 2 psi) onto cells from a nearby $3 \mathrm{M} \Omega$ pipette (tip diameter, $1 \mu \mathrm{m}$ ). An electronically gated pressure valve allowed precise timing of "puffer" activation. The voltage step that activated the solenoid was recorded along with membrane current and voltage from the hair cell. The puffer stream was spatially precise so that when directed at the base of the cell it could elicit ACh-evoked membrane current, but when pointed at an appropriately oriented hair bundle, could be made to activate transducer current (Fig. $1 B$ ). Delivery time of the puffer system was calibrated by measurement of the delay to activation of the transducer current. Alternatively, saline containing a concentration of $\mathrm{K}^{+}$that differed from that of the bathing medium could be directed at the base of the cell and elicit a change in holding current (see Fig. 9). The time between puff initiation and onset of transducer current or $\mathrm{K}^{+}$-evoked current ranged from 10 to $48 \mathrm{msec}$ in different recordings (as a result of different positioning of the puffer in each case). All recordings were made at room temperature $\left(21-23^{\circ} \mathrm{C}\right)$.

Various solutions were used to examine the ionic dependence of the $\mathrm{ACh}$ response. The standard extracellular saline contained (in $\mathrm{mM}$ ) 154 $\mathrm{NaCl}, 6 \mathrm{KCl}, 2.3 \mathrm{MgCl}_{2}, 5.6 \mathrm{CaCl}_{2}, 5$ HEPES, and 8 glucose, $\mathrm{pH} 7.4$ (adjusted with $\mathrm{NaOH}$ ). $\mathrm{Ca}^{2+}$-free saline contained additional $\mathrm{Mg}^{2+}(5.6$ mM) in place of $\mathrm{Ca}^{2+}$, plus $1 \mathrm{mM}$ EGTA. The standard intracellular (patch pipette) solution contained (in $\mathrm{mM}$ ) $112 \mathrm{KCl}, 2 \mathrm{MgCl}_{2}, 0.1 \mathrm{CaCl}_{2}$, $30 \mathrm{KOH}, 11$ EGTA, $10 \mathrm{HEPES}$, and $5 \mathrm{Na}_{2}-\mathrm{ATP}$, pH 7.2 (adjusted with $\mathrm{KOH}$ ). Bis(2-aminophenoxy)ethane- $N, N, N^{\prime}, N^{\prime}$,-tetraacetic acid (BAPTA; Molecular Probes, Eugene, OR, 5 or $10 \mathrm{mM}$ ) was substituted for EGTA in some cases. The $\mathrm{K}^{+}$equilibrium potential, $E_{\mathrm{K}}$, was derived from the concentrations of $\mathrm{K}^{+}$in the extracellular and intracellular solutions (i.e., assuming complete replacement of cytoplasmic ions by those in the pipette) and was altered in different recordings by appropriate mixture of the standard intracellular solution with one in which $\mathrm{Cs}^{+}$substituted for $\mathrm{K}^{+}$. All salts and buffers (except BAPTA) were obtained from Sigma (St. Louis, MO).

\section{Results}

\section{Voltage response to $A C h$}

SHCs of the bird's cochlea, like outer hair cells in mammals, are innervated selectively by efferent neurons (Takasaka and Smith, 1971; Hirokawa, 1978; Tanaka and Smith, 1978; Firbas and Muller, 1983). Thus, one might expect that SHCs, but not tall hair cells (THCs; analogous to mammalian inner hair cells), should respond to $\mathrm{ACh}$. The 68 cells that were sensitive to $\mathrm{ACh}$ in this study had apical surface diameters that were larger than their somatal length; that is, they were short cells according to the criteria of Tanaka and Smith (1978). The ratio of width to length was greater than 1.5 in 57 of those. In contrast, 14 THCs showed no response to $\mathrm{ACh}$. The cells in this study came from a region ranging from 0.5 to $2 \mathrm{~mm}$ from the apex of the chick's cochlea. (It proved difficult to find cells in more apical positions that responded to $\mathrm{ACh}$.) In a separate, more restricted comparison of THCs and SHCs isolated from a region $0.6-1.2 \mathrm{~mm}$ from the cochlear apex, 17 of 19 SHCs responded to $100 \mu \mathrm{M}$ carbachol and 16 of 16 THCs did not (Murrow and Fuchs, 1990b).
A
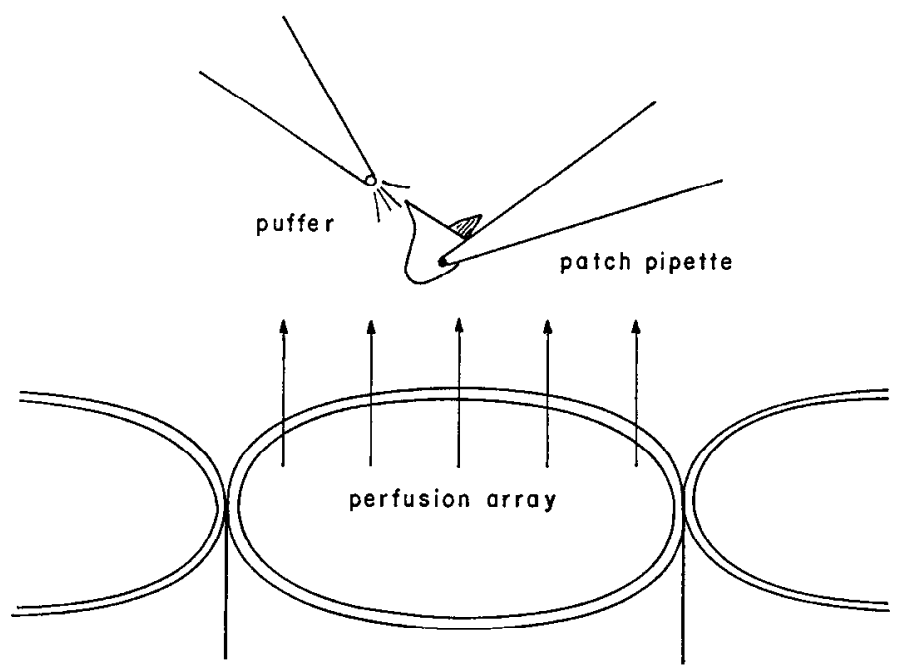

$B$

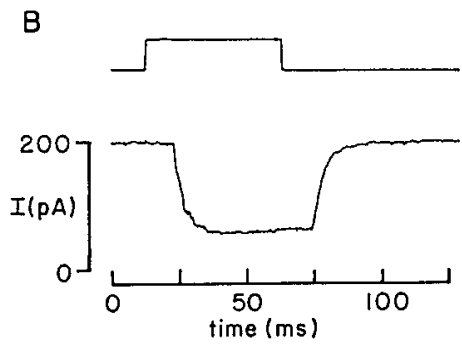

Figure 1. The experimental arrangement. $A$, Membrane potential or current was recorded from hair cells with patch pipettes. Agonists were applied to the cell from the "puffer," or from the perfusion array, other tubes of which contained antagonists or saline with altered ion composition. (Perfusion array is not drawn lo scale.) $B$, When the puffer was directed at the hair bundle, transducer currents could be elicited. These reversed at $0 \mathrm{mV}\left(E_{\mathrm{K}},-80 \mathrm{mV} ; E_{\mathrm{Na}},+50 \mathrm{mV}\right)$ and did not desensitize with repeated presentation. Average of 19 responses to the puffer stream (indicated above); holding potential, $-84 \mathrm{mV}$. Delay from puffer signal to current onset was $10.5 \mathrm{msec}$; delay from puffer off to decay of current was 10.3 msec. Puffer not directed at the hair bundle produced no such response (not shown).

Application of $100 \mu \mathrm{M}$ ACh caused SHCs to hyperpolarize (Fig. 2). The resting membrane potential of these cells was near $-40 \mathrm{mV}$ on average (also see Murrow and Fuchs, 1990a), and they could hyperpolarize to as much as $-70 \mathrm{mV}$ in the presence of ACh. The hyperpolarization rose to a peak within $100 \mathrm{msec}$ and declined over several seconds in the continued presence of the agonist (not shown). The change in membrane potential produced by $\mathrm{ACh}$ could be reversed in sign by hyperpolarizing the cell. When the membrane potential was made more negative than $-70 \mathrm{mV}$ by current injection through the recording pipette, ACh elicited an entirely depolarizing response (Fig. 2, record at $-82 \mathrm{mV}$ ). In three cells the ACh-evoked hyperpolarization reversed in sign at $-69 \pm 4 \mathrm{mV}( \pm \mathrm{SD})$. The potassium equilibrium potential $\left(E_{\mathrm{K}}\right)$ was $-80 \mathrm{mV}$.

Alteration of the cell's membrane potential also revealed that the effect of $\mathrm{ACh}$ was more complex than at first noted. At membrane potentials negative to rest a brief depolarization was observed preceding the longer-lasting hyperpolarization (Fig. 2, record at $-69 \mathrm{mV}$ ). 
Figure 2. Hair cell voltage response to ACh. Superfusion with $100 \mu \mathrm{M}$ ACh caused a $28 \mathrm{mV}$ hyperpolarization ( $u p$ permost record) in this SHC. (Apical surface diameter of the cell was $12 \mu \mathrm{m}$; length, $5 \mu \mathrm{m}$ ). The cell was hyperpolarized to membrane potentials listed beside each record by steady current injection. The vertical broken line shows the time of voltage measurements used to measure the reversal potential of -69 $\mathrm{mV}$.

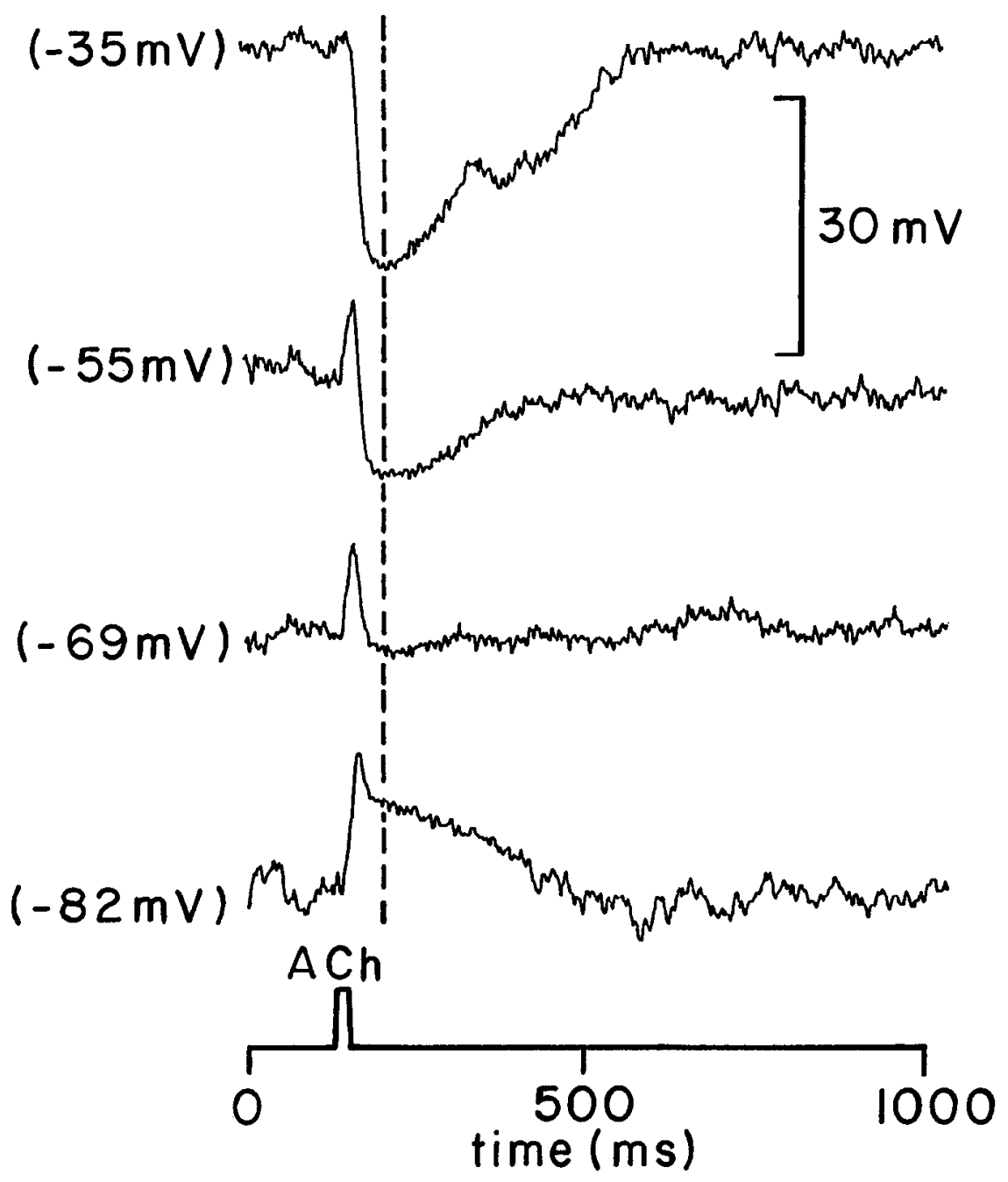

potential was made more negative, a smaller inward current could be seen preceding the predominant outward current (Fig. 4). This occurred as the driving force on the outward current was diminished and that on the inward current enhanced. The inward current was visible for 5-10 msec (depending on membrane potential) before being eclipsed by the outward current. Thus, both the voltage change and the membrane current elicited by ACh were biphasic. As will be seen, the somewhat occult early component is crucial to the mechanism of action of $\mathrm{ACh}$. However, its characterization will be treated later, after a consideration of the larger, later outward current that is responsible for inhibition of the hair cell.

\section{The ionic dependence of the late outward current}

Membrane currents evoked by $\mathrm{ACh}$ were studied as a function of membrane potential in voltage clamp. The slope of the current-voltage relation for the $\mathrm{ACh}$-evoked current was relatively constant between -80 and $-40 \mathrm{mV}$ but varied considerably outside that range (see below). The conductance increase produced by $100 \mu \mathrm{M} A C h$ varied from cell to cell, ranging from 3.7 to $16.7 \mathrm{nS}(7.6 \pm 4.7 \mathrm{nS}$, mean $\pm \mathrm{SD}$ in seven cells, chord conductance calculated at the resting potential). When the holding potential was made more negative than rest, the outward current became smaller and reversed in sign just positive to $E_{\mathrm{K}}$ (which was $-80 \mathrm{mV}$ in these experiments) (Fig. 4). The reversal 


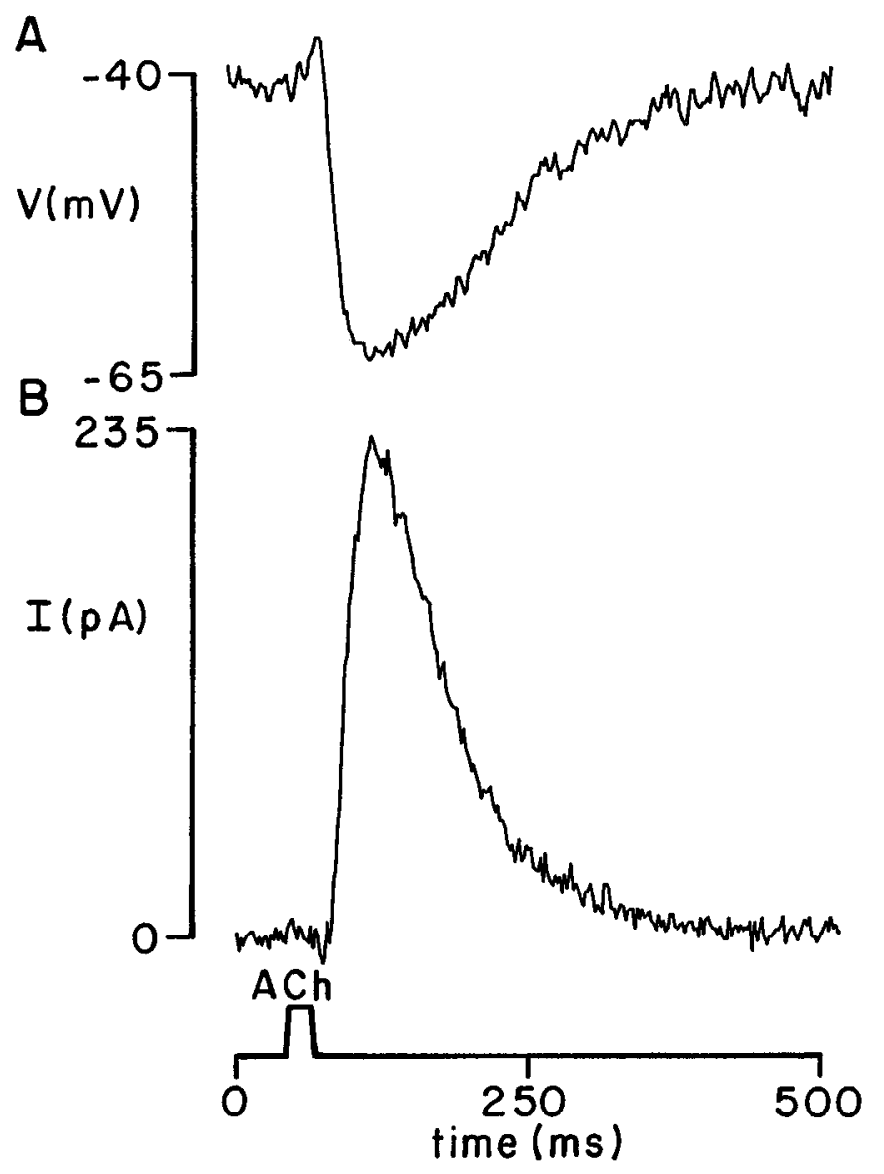

Figure 3. An outward current gave rise to the ACh-evoked hyperpolarization: voltage change $(A)$ and voltage-clamped ionic current $(B)$ in response to $\mathrm{ACh}$ at $-40 \mathrm{mV}$ in one cell. The hyperpolarization reached its peak $76 \mathrm{msec}$ after the start of the puffer signal, had a half-amplitude duration of $151 \mathrm{msec}$, and was preceded by a small depolarization. In voltage clamp in the same cell, the outward current evoked by ACh rose to its peak $76 \mathrm{msec}$ after the start of the puffer signal, had a halfamplitude duration of $87 \mathrm{msec}$, and was preceded by a small inward current.

potential of ACh-evoked inhibitory current in seven cells was $-71.4 \pm 5.9 \mathrm{mV}$ (mean $\pm \mathrm{SD}$ ), suggesting that $\mathrm{K}^{+}$ions were the major charge carriers.

The reversal potential of the late ACh-evoked current was altered when some of the $\mathrm{KCl}$ in the recording pipette was replaced with $\mathrm{CsCl}$. The results from a series of such experiments is illustrated in Figure 5. When $E_{\mathrm{K}}$ was set to $-40 \mathrm{mV}$ by partial replacement of internal $\mathrm{K}^{+}$with $\mathrm{Cs}^{+}$, the late current reversed near the new $E_{\mathrm{K}}$. In four cells the average reversal potential under these conditions was $-36.8 \mathrm{mV}( \pm 2.5 \mathrm{mV} \mathrm{SD})$. In one cell $E_{\mathrm{K}}$ was set to $-60 \mathrm{mV}$ by a lesser change in internal $\mathrm{K}^{+}$ and the $\mathrm{ACh}$-evoked current reversed at $-56 \mathrm{mV}$. The reversal

Figure 4. Reversal potential of ACh-evoked current. A, ACh was applied from the perfusion array for the time indicated by the upper bar. The membrane potential was changed to the values indicated beside each record. $B, I / V$ relation obtained from data in $A$ plus additional points. Peak ACh-evoked current plotted (holding current subtracted; input resistance between -80 and $-40 \mathrm{mV}$ was $1.5 \mathrm{G} \Omega$ ). Reversal occurred in this cell at $-77 \mathrm{mV}$. Note the residual inward transient at $-79 \mathrm{mV}$ in $A$.
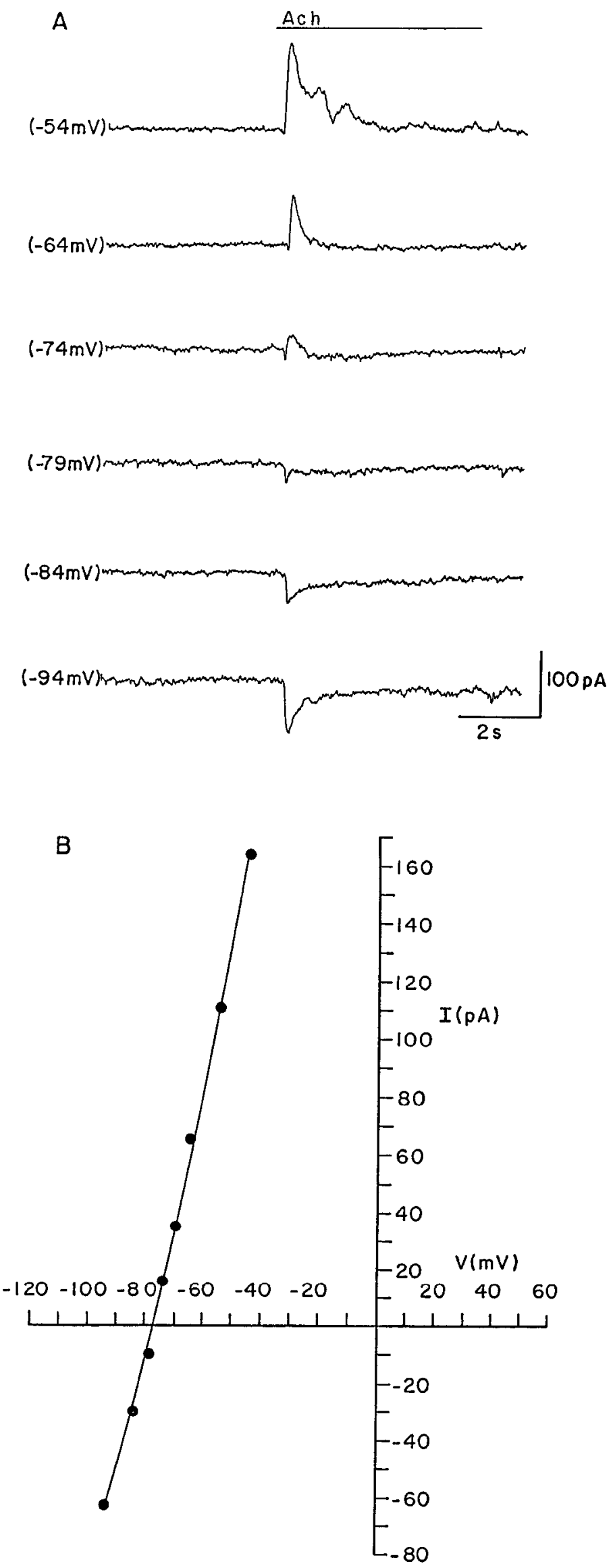


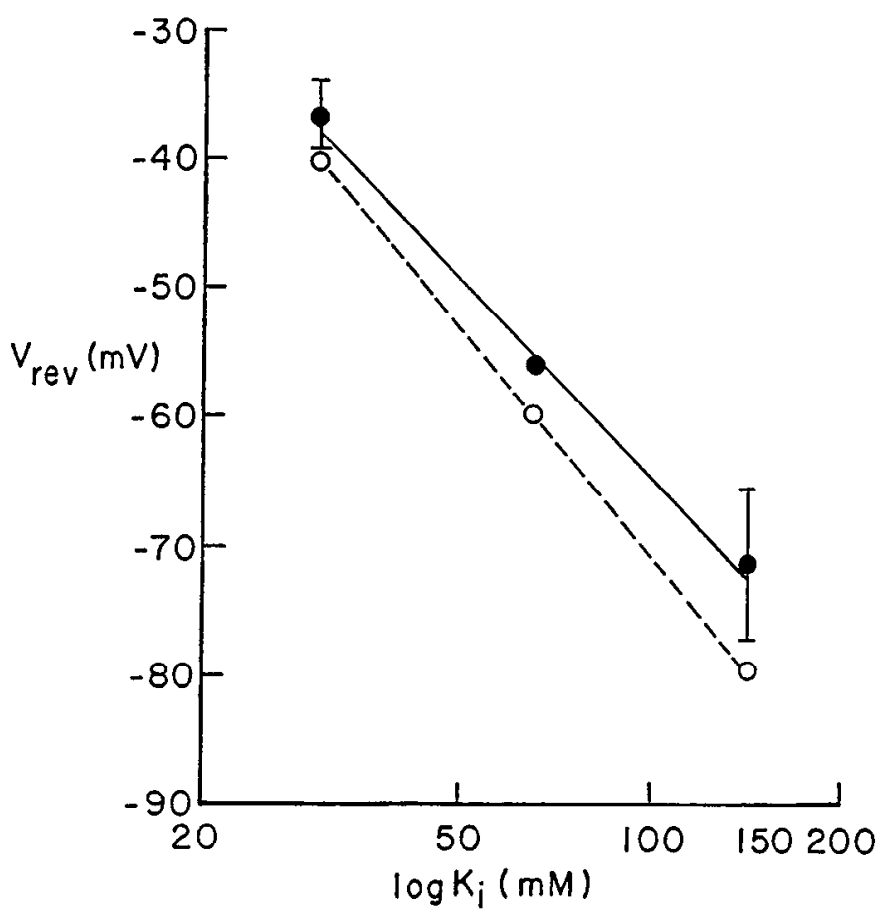

Figure 5. Relation between the reversal potential of the ACh-evoked current and the $\log$ of the internal $\mathrm{K}^{+}$concentration (external $\mathrm{K}^{+}$held constant at $6 \mathrm{mM}$; solid symbols and solid line). Slope, $51 \mathrm{mV}$. Internal $\mathrm{K}^{+}$concentration was altered by substitution with $\mathrm{Cs}^{+}$. Means and SD are indicated for four cells at the lowest and seven cells at the highest concentrations (solid symbols). Only one cell was measured at middle point. Open symbols and broken line were calculated from the Nernst equation for $\mathrm{K}$; slope, $58 \mathrm{mV}$.

potential varied $51 \mathrm{mV}$ for a 10 -fold change in $\mathrm{K}^{+}$concentration (Fig. 5). These results support the conclusion that the late $\mathrm{ACh}$ evoked current was carried primarily by $\mathrm{K}^{+}$. The lesser slope of this relation compared to that of the Nernst equation for $\mathbf{K}^{\prime}$ probably arises from the contribution of the underlying inward current (see below).

Two additional features of the ACh-evoked current were noted in these reversal potential measurements. First, the early inward current that was described previously (Fig. 3) became more evident near the reversal potential of the late current (Fig. $4 A$, record at $-79 \mathrm{mV}$ ). Second, the $I / V$ relation of the AChevoked current was not monotonic. Although the outward current grew progressively larger with depolarization in the voltage range of -70 to $-10 \mathrm{mV}$, this trend reversed at $0 \mathrm{mV}$, and the current diminished with progressive depolarization (Fig. 6A,B). There was also a suggestion that the rate of rise of the $\mathrm{K}^{+}$current slowed at membrane potentials near $0 \mathrm{mV}$ (Fig. $6 \mathrm{~A}$, record at $-4 \mathrm{mV}$ ). This same behavior was observed in five additional cells, and in all cases the peak current was seen between -15 and $0 \mathrm{mV}$. The decrease in outward current with depolarization is reminiscent of that displayed by the $\mathrm{Ca}^{2+}$-activated "maxi" $\mathrm{K}^{+}$current, $I_{\mathrm{K}(\mathrm{Ca})}$, in chick hair cells (Ohmori, 1984; Fuchs et al., 1988; Fuchs and Evans, 1990). $I_{\mathrm{K}(\mathrm{Ca})}$ diminishes at positive membrane potentials because the driving force on $\mathrm{Ca}^{2+}$ influx is reduced.

Despite this similarity, it is unlikely that the ACh-evolved $\mathrm{K}^{+}$current $I_{\mathrm{K}(\mathrm{ACh})}$ flows through the same channels that carry $I_{\mathrm{K}(\mathrm{Ca})}$. The most telling evidence in this regard is that internal $\mathrm{Cs}^{+}$ions block $I_{\mathrm{K}(\mathrm{Ca})}$ (Fuchs et al., 1990) but had no such effect on $I_{\mathrm{K}(\mathrm{ACh})}$. The mean conductance increase produced by $\mathrm{ACh}$ in cells loaded with $112 \mathrm{mM} \mathrm{CsCl}$ in place of $\mathrm{KCl}$ was $6.6 \mathrm{nS}( \pm 4.1$ $\mathrm{nS} \mathrm{SD)}$ at $-40 \mathrm{mV}$, compared to $7.6 \mathrm{nS}$ with normal internal $\mathrm{KCl}\left(\right.$ at $-40 \mathrm{mV}$ ). In $\mathrm{Cs}^{+}$-loaded cells $I_{\mathrm{K}(\mathrm{ACh})}$ still had a bellshaped $I / V$ relation, also peaking near $-10 \mathrm{mV}$ (not shown). In these cells $I_{\mathrm{K}(\mathrm{Ca})}$ was completely blocked.

\section{The $\mathrm{Ca}^{2+}$ dependence of the late $\mathrm{K}^{+}$current}

Our observation of an inward current preceding the predominant late $\mathrm{K}^{+}$current, and the bell-shaped $I / V$ relation of that $\mathrm{K}^{+}$current led us to examine the possibility that $\mathrm{Ca}^{2+}$ influx played a role in the cholinergic response. When $\mathrm{ACh}$ was applied to hair cells in a $\mathrm{Ca}^{2+}$-free saline (substituted with $\mathrm{Mg}^{2+}$ ), a much smaller or no response was observed (Fig. 7). To ensure that the $\mathrm{Ca}^{2+}$-free solution reached the hair cell, we simultaneously activated $I_{\mathrm{K}(\mathrm{Ca})}$ with voltage commands, thus establishing an independent indicator of the actual solution change. These are seen as the brief outward currents in Figure 7 . The arrival of the $\mathrm{Ca}^{2+}$-free $\mathrm{ACh}$ solution is indicated by the sharp reduction in these currents (Fig. $7 B$ ). During this period little or no ligandactivated outward current was seen, whereas superfusion with $\mathrm{ACh}$ in the presence of $\mathrm{Ca}^{2+}$ elicited a notable outward current from the same cell (Fig. 7A). Superfusion with $\mathrm{Ca}^{2+}$-free $\mathrm{ACh}$ solution was performed 28 times on six hair cells and resulted in complete elimination of the response in 13 trials and reduction in comparison to the control response in 15 trials. Incomplete elimination might occur if there was some mixing of the experimental perfusion stream with the surrounding saline.

A second approach was taken to examine the $\mathrm{Ca}^{2+}$ dependence of the cholincrgic response, and this involved the use of a potent $\mathrm{Ca}^{2+}$ buffer in the intracellular solution. The standard intracellular (pipette) solution used in these experiments included 11 mM EGTA. This might be expected to prevent $\mathrm{Ca}^{2+}$-activated processes from occurring. However, the $I_{\mathrm{K}(\mathrm{Ca})}$ that is activated by influx through voltage-gated $\mathrm{Ca}^{2+}$ channels in hair cells (Fuchs et al., 1990) is not prevented by intracellular EGTA (Lewis and Hudspeth, 1983; Art and Fettiplace, 1987; Fuchs and Evans, 1988, 1990; Fuchs et al., 1988; Hudspeth and Lewis, 1988). In contrast, the $\mathrm{Ca}^{2+}$ buffer BAPTA has more rapid binding kinetics with $\mathrm{Ca}^{2+}$ than does EGTA (Tsien, 1980) and was reported to prevent activation of $I_{\mathrm{K}(\mathrm{Ca})}$ in turtle hair cells (Art and Fettiplace, 1987). BAPTA, but not EGTA, also was able to prevent transmitter release at the squid giant synapse (Adler et al., 1991). Thus, we used BAPTA as the internal $\mathrm{Ca}^{2+}$ buffer in an additional attempt to prevent activation of the $\mathrm{ACh}$-evoked $\mathrm{K}^{+}$current.

ACh-evoked current recorded at $-40 \mathrm{mV}$ from a cell loaded with $5 \mathrm{~mm}$ K-BAPTA is shown in Figure $8 B$. A recording at the same holding potential from a cell loaded with $11 \mathrm{mM}$ EGTA is shown for comparison (Fig. $8 A$ ). In both cells $E_{\mathrm{K}}$ was -80 $\mathrm{mV}$. Only inward current was seen with the cell loaded with 5 mм K-BAPTA, while the usual combination of small inward and larger outward current was seen in the EGTA-loaded cell. This concentration of BAPTA produced qualitatively similar effects in five cells; that is, only inward currents were seen under conditions in which EGTA-loaded cells produced large outward currents in response to $\mathrm{ACh}$.

The onset of the effect of 5 mM BAPTA could be observed if ACh responses were elicited within 1-2 min of achieving the whole-cell recording (Fig. $8 C, D$ ). Initial recordings from a BAPTA-loaded cell showed small inward and much larger outward currents (Fig. 8C), as usually seen in EGTA-loaded cells. More than 2 min after the beginning of the whole-cell recording, only 
A
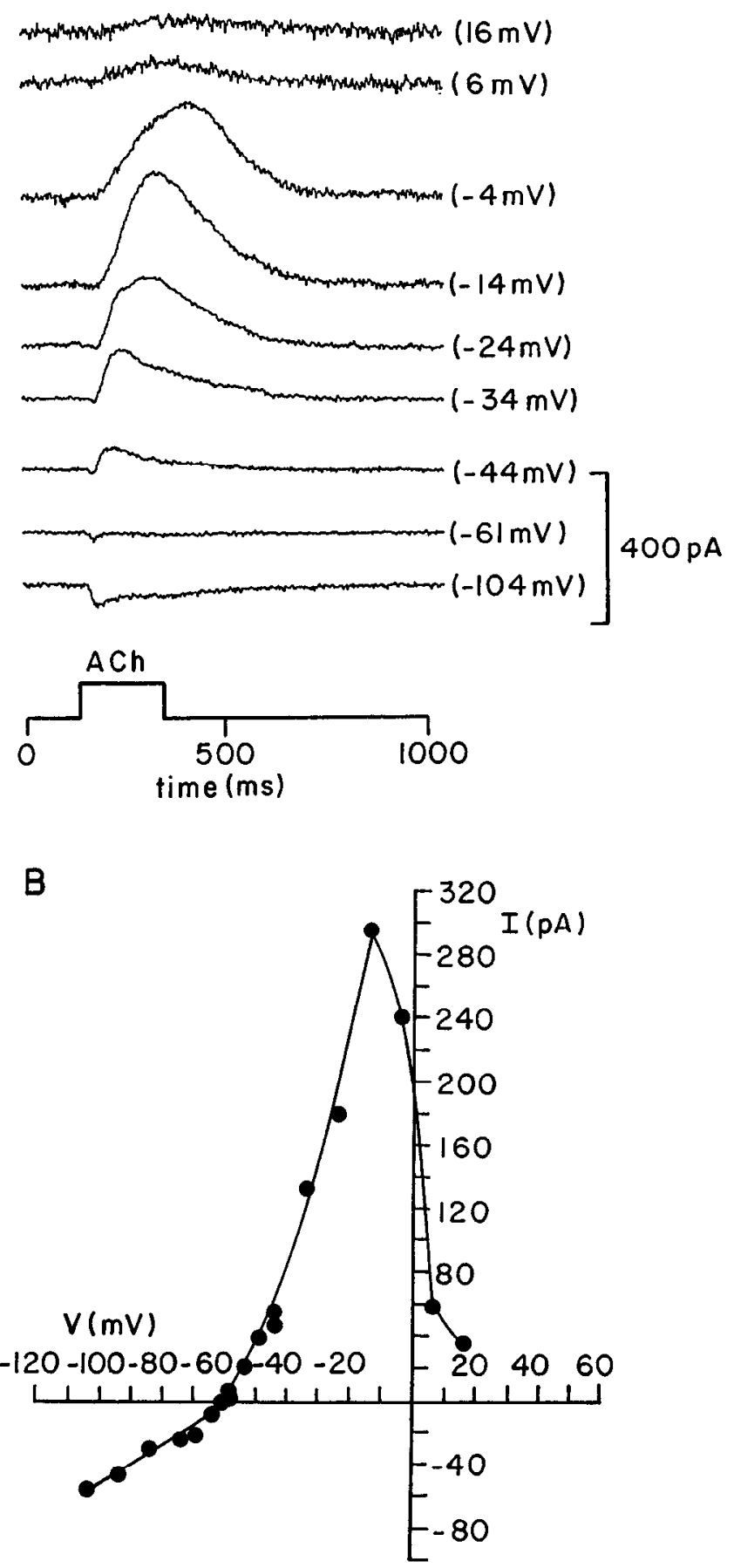

Figure 6. ACh-evoked current decreased at positive membrane potentials. $A$, Current evoked by $\mathrm{ACh}$ at listed membrane potentials. Records are displaced vertically from one another for clarity. $B, A C h$-evoked current from records in $A$ and others are plotted as a function of membrane potential. Smooth curves were fit by eye.

inward current was elicited by ACh application in the same cell (Fig. $8 D$ ). That is, it took more than 1 min for $5 \mathrm{~mm}$ BAPTA to reach an effective concentration within the cell. This is in contrast to the rapid movement of $\mathrm{Cs}^{+}$ions, which block $\mathrm{K}^{+}$ currents within seconds of beginning whole-cell recording (Fuchs et al., 1990) and may reflect the slower diffusion of BAPTA compared to $\mathrm{Cs}^{+}$. Alternatively, BAPTA may fill the cell more rapidly, but only gradually deplete a $\mathrm{Ca}^{2+}$ store such as the
A

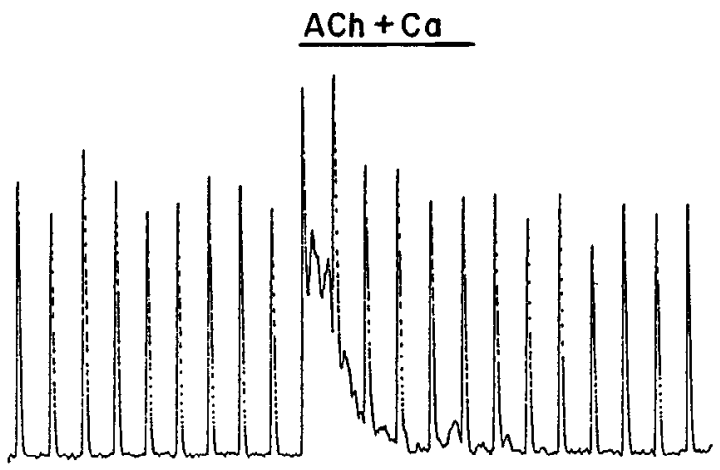

B

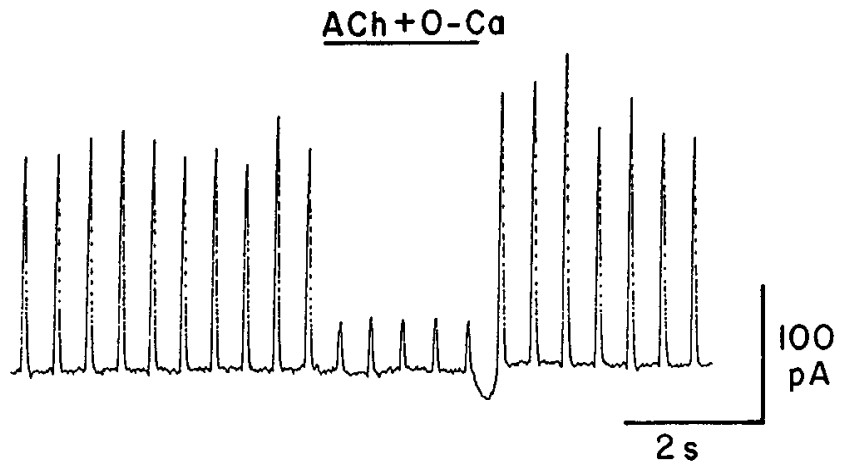

Figure 7. The response to $\mathrm{ACh}$ was prevented in $\mathrm{Ca}^{2+}$-free saline. Repeated voltage commands from -44 to $-4 \mathrm{mV}$ elicited brief spikes of outward current (largely $\left.I_{\mathrm{K}\left(\mathrm{C}_{a}\right)}\right) . A$, One tube of the perfusion array contained $\mathrm{ACh}$ in standard saline, and superfusion of that solution produced the usual outward current. $B, A C h(100 \mu \mathrm{M})$ in $\mathrm{Ca}^{2+}$-free saline was superfused onto the cell from the perfusion array. The arrival of the test solution is signaled by the fall in $I_{\mathrm{K}(\mathrm{Ca})}$; however, no response to $\mathrm{ACh}$ was seen. The residual outward current during the voltage step was a combination of leak current and a small amount of $I_{\mathrm{K}}$, the delayed rectifier.

subsynaptic cistern associated with the efferent ending (see Discussion). In any event, these experiments using BAPTA confirmed that the late $\mathrm{K}^{+}$current depended on a rise in internal $\mathrm{Ca}^{2+}$ for its activation.

\section{Characterization of the early inward current}

The elimination of the late outward current by intracellular BAPTA allowed an examination of the properties of the early inward current in isolation. With $5 \mathrm{~mm}$ BAPTA the outward current was not immediately or irrevocably eliminated in every cell, and so additional experiments were performed with $10 \mathrm{~mm}$ BAPTA and $112 \mathrm{~mm} \mathrm{CsCl}$ in the intracellular solution. Intracellular $\mathrm{Cs}^{+}$preventcd voltagc-dependent outward currents and so allowed extended depolarization of the cell during currentvoltage measurements.

In cells loaded with the Cs/BAPTA solution, the early inward current activated rapidly and had a duration of one hundred to several hundred msec following a brief puff of $\mathrm{ACh}$. The time delay between the puffer signal and the early inward current ranged from 13 to $57 \mathrm{msec}$ in different cells. Since the onset delay of transducer current ranged from 10 to $48 \mathrm{msec}$ (as in Fig. 1), depending on pipette position, this comparison suggests that $\mathrm{ACh}$-evoked current arose virtually as soon as $\mathrm{ACh}$ was 


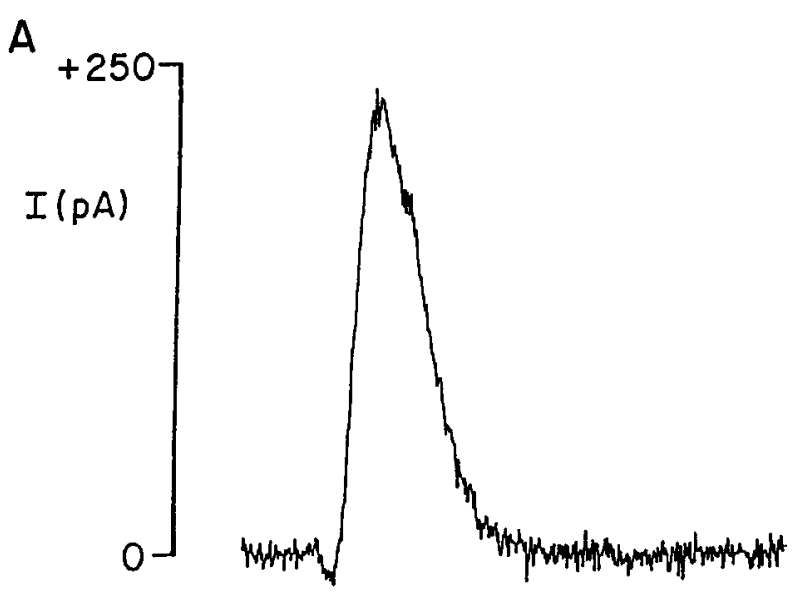

B

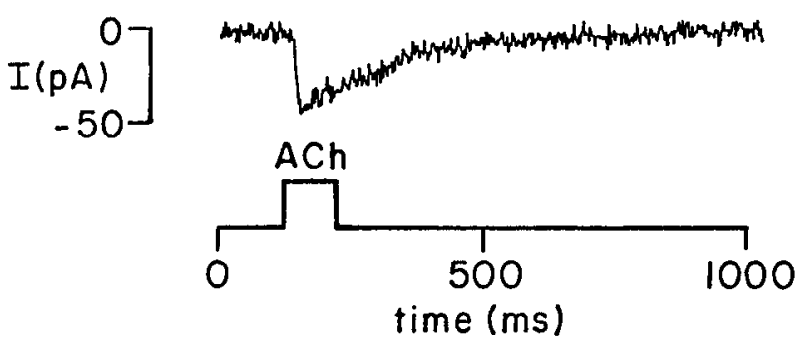

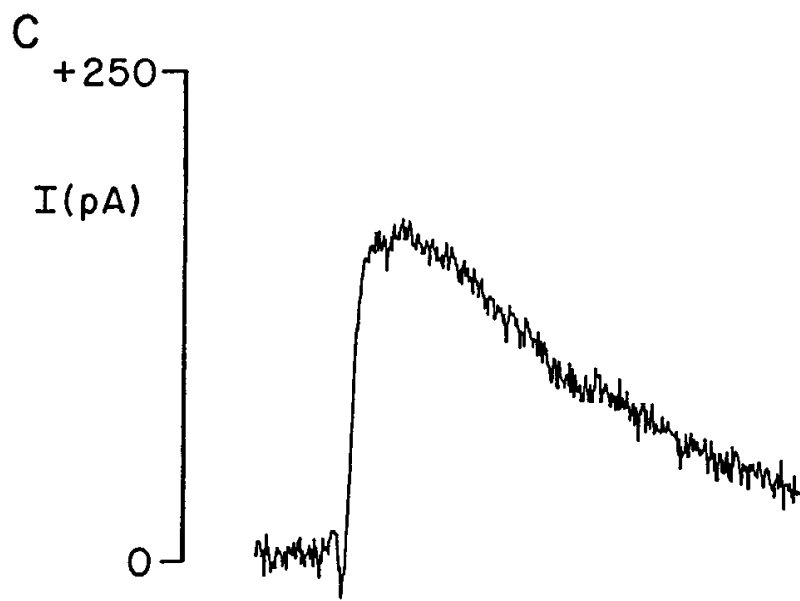

D

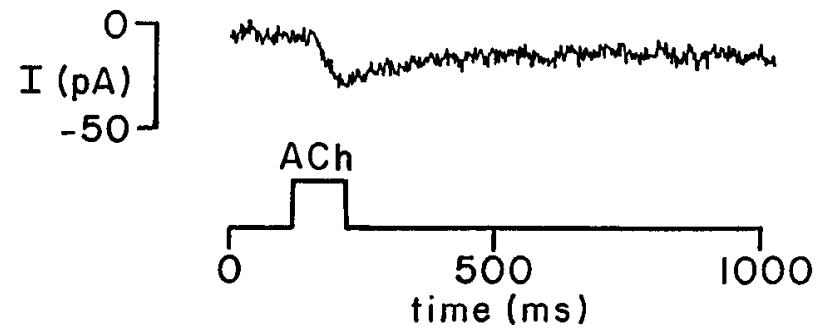

Figure 8. Buffering internal $\mathrm{Ca}^{2+}$ with BAPTA prevented the outward current. $A$, ACh-evoked currents at $-44 \mathrm{mV}$ from a cell loaded with the usual $11 \mathrm{~mm}$ EGTA. $E_{\mathrm{K}}$ was $-80 \mathrm{mV}$. $B$, ACh-evoked current at $-44 \mathrm{mV}$ from a cell loaded with $5 \mathrm{~mm}$ BAPTA. $E_{\mathrm{K}}$ was $-80 \mathrm{mV}$. $C$ and $D$, Forty-five seconds $(C)$ and $150 \mathrm{sec}(D)$ after the start of whole-cell recording in one cell. The pipette contained 5 mM BAPTA. Initially $(C)$, inward and outward current were evoked by $\mathrm{ACh}$ at $-54 \mathrm{mV}$. Two minutes later $(D)$, ACh resulted in only inward current at $-44 \mathrm{mV} . E_{\mathrm{K}}$ was $-80 \mathrm{mV}$ in this recording.

delivered by the puffer pipette. The intrinsic delay of ACh's action was examined directly in one cell by comparing it to delivery of an experimental $\mathrm{K}^{+}$solution by the same pipette (Fig. 9). In this cell, ACh-evoked inward current began 18.5 msec after the start of the puffer signal. Later that same cell was superfused with a $60 \mathrm{~mm} \mathrm{~K} \mathrm{~K}^{+}$solution from the perfusion array, causing a steady $30 \mathrm{pA}$ inward current. Then, a $6 \mathrm{mM} \mathrm{K}^{+}$solution was cjected from the puffer pipctte with the same timing as in Figure $9 A$. This resulted in an outward current (reduction of the standing inward current) after a delay of $17 \mathrm{msec}$ from the puffer signal (Fig. 9B). Thus, the ACh-evoked current, and one arising from a direct action of $\mathrm{K}^{+}$ions on the membrane, had nearly identical timing. These findings suggest that $\mathrm{ACh}$ interacts directly with a receptor/ion channel complex to produce the early inward current in hair cells, and not by way of a second messenger.

\section{The current-voltage relation of the early current}

The current-voltage relationship of the early current was studied in cells that had been loaded with BAPTA. In four experiments the cells were loaded with $10 \mathrm{~mm}$ BAPTA and $112 \mathrm{~mm}$ of the $\mathrm{KCl}$ was substituted with $\mathrm{CsCl}$ so that $E_{\mathrm{K}}$ was $-40 \mathrm{mV}$. Under these conditions the remaining current was inward at negative membrane potentials, including those positive to $E_{\mathrm{K}}$ (Fig. 10A). The conductance increase measured between 0 and $-40 \mathrm{mV}$ averaged $0.8 \mathrm{nS}( \pm 0.3 \mathrm{nS} \mathrm{SD})$ in four cells. At positive membrane potentials the ACh-evoked current became outward, in- dicating a reversal potential of $+3 \mathrm{mV}$ (Fig. 10B). A reversal potential near $0 \mathrm{mV}(4.5 \pm 2.0 \mathrm{mV}$, mean $\pm \mathrm{SD} ; n=4$ cells $)$ suggests that the early current flowed through a nonspecific cation channel since the equilibrium potentials for $\mathrm{K}^{+}$and $\mathrm{Na}^{+}$ were -40 and $+51 \mathrm{mV}$, respectively. In another cell $E_{\mathrm{K}}$ was set at $-80 \mathrm{mV}$ (no intracellular $\mathrm{CsCl} ; E_{\mathrm{Na}}$ was unchanged) and the early current reversed at $-17 \mathrm{mV}$. Thus, the result of shifting $E_{\mathrm{K}}$ by $40 \mathrm{mV}$ was to produce a $20 \mathrm{mV}$ shift in the reversal potential, consistent with the idea that $\mathrm{K}^{+}$carries a portion of the charge through the open channels, as expected for a nonspecific cation channel. That is, although an influx of $\mathrm{Ca}^{2+}$ is required for the cholinergic inhibition of SHCs, that $\mathrm{Ca}^{2+}$ influx must be only part of the cationic current flowing through the hair cell AChR.

\section{Discussion}

ACh caused a hyperpolarization of SHCs (short, outer hair cells) isolated from the chick's cochlea, and in voltage clamp that hyperpolarization was seen to arise from an increase in $\mathrm{K}^{+}$conductance. ACh had no effect on THCs (tall, inner hair cells) reflecting the distribution of cochlear efferent endings in birds (Firbas and Muller, 1983). The ACh-evoked $\mathrm{K}^{+}$current, $I_{\mathrm{K}(\mathrm{ACh})}$, had an anomalous voltage dependence, diminishing at positive membrane potentials, reminiscent of the behavior of $\mathrm{Ca}^{2+}$-activated $\mathrm{K}^{+}$current. Reinforcing this comparison, removal of external $\mathrm{Ca}^{2+}$ prevented activation of $I_{\mathrm{K}(\mathrm{ACh})}$. Furthermore, intracellular perfusion with BAPTA also prevented activation of 
A

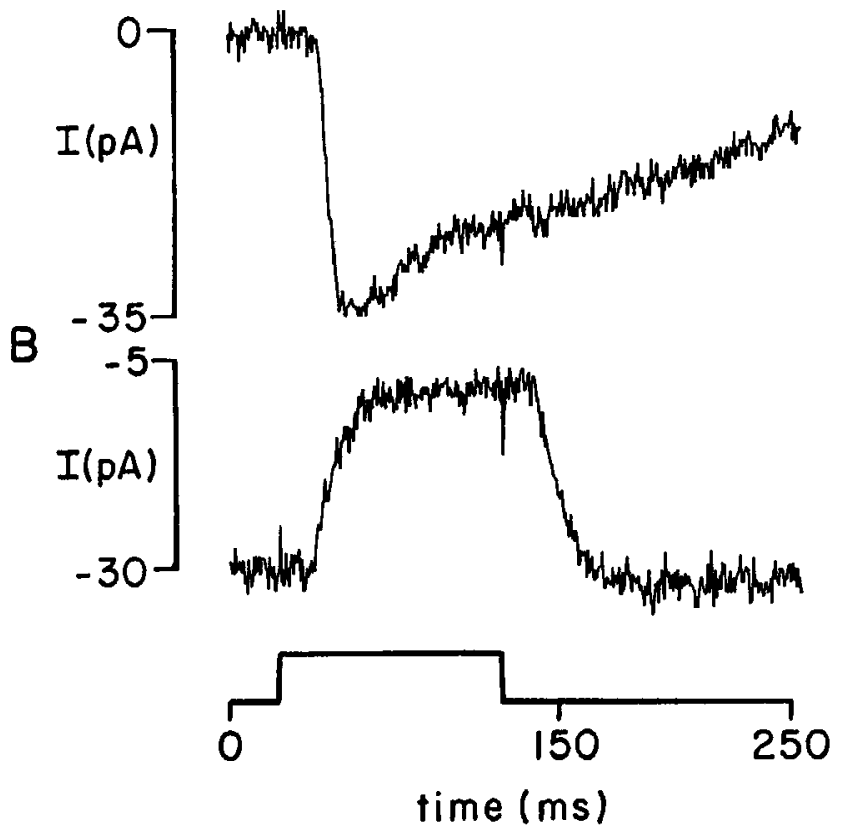

A
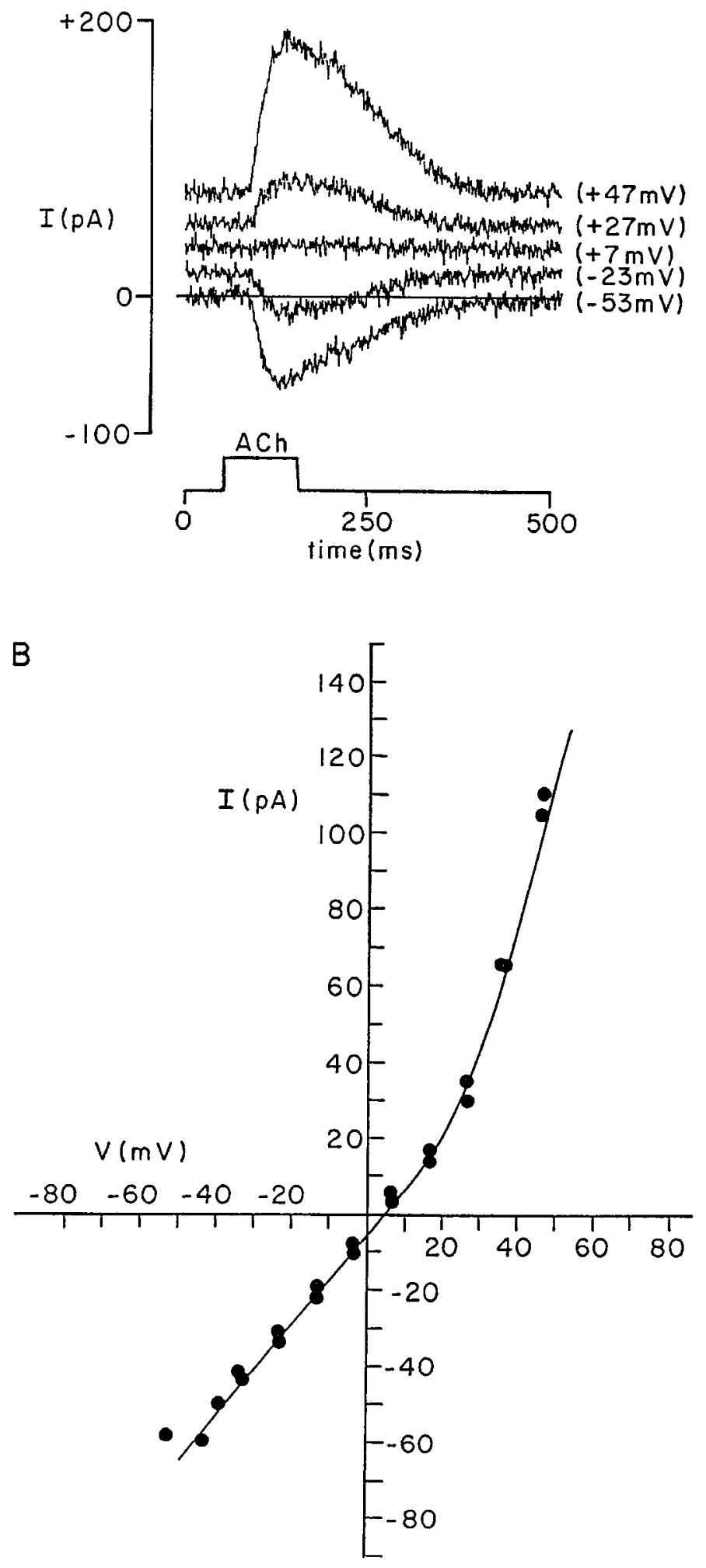

Figure 10. The $I / V$ relation of the early current. $A$, ACh-evoked current at the listed membrane potentials in a cell loaded with $10 \mathrm{~mm}$ BAPTA. $E_{\mathrm{K}}$ was $-40 \mathrm{mV}$ in this recording due to replacement of some internal $\mathrm{K}^{+}$with $\mathrm{Cs}^{+} . B, I / V$ relation from records in $A$ plus others. Smooth curve was fit by eye. Reversal occurred at $+3 \mathrm{mV}$ in this cell.
Figure 9. The isolated inward current activated rapidly. $A$, A small ACh-evoked inward current activated $18.5 \mathrm{msec}$ after the start of the puffer signal in a cell loaded with 5 mM BAPTA (average of six records at $-54 \mathrm{mV}$ holding potential). $E_{\mathrm{K}}$ was $80 \mathrm{mV}$. $B$, The same cell was continuously superfused with $60 \mathrm{mM} \mathrm{K}^{+}$saline from the perfusion array, which resulted in an inward current of $30 \mathrm{pA}$ at $-54 \mathrm{mV}$. When the puffer ejected $6 \mathrm{mM} \mathrm{K}^{+}$saline, that inward current was reduced, seen as the outward current in $B$. The delay to onset of this current change was $17 \mathrm{msec}$. The timing bar below indicates the application of $\mathrm{ACh}$ in $A, 6 \mathrm{mM} \mathrm{K}^{+}$in $B$.

$I_{\mathrm{K}(\mathrm{ACh})}$. In BAPTA-loaded cells a residual inward current was observed, and this appeared to be a nonspecific cation current since it reversed near $0 \mathrm{mV}$. The simplest interpretation of these results is that the hair cell AChR is a ligand-gated cation channel, not unlike the nicotinic receptor of nerve and muscle. When activated by $\mathrm{ACh}$ this channel opens and the resulting influx of ions, including some $\mathrm{Ca}$, activates nearby $\mathrm{K}^{+}$channels. This mechanism of cholinergic inhibition may also occur more generally (Wong and Gallagher, 1991).

One difficulty with this interpretation is that $I_{\mathrm{K}(\mathrm{ACh})}$ disappears at membrane potentials far negative to the $\mathrm{Ca}^{2+}$ equilibrium potential (approximately $+200 \mathrm{mV}$ in these recordings). At 0 to $+20 \mathrm{mV}$, where $I_{\mathrm{K}(\mathrm{ACh})}$ is markedly reduced, $\mathrm{Ca}^{2+}$ influx through the nonspecific cation channel will be only slightly diminished (although the net ionic flux is now outward). Several explanations might be advanced. $\mathrm{Ca}^{2+}$ binding to the $\mathrm{K}^{+}$channels might be cooperative, leading to the requirement for a "threshold" concentration of $\mathrm{Ca}^{2+}$. Other $\mathrm{Ca}^{2+}$-activated $\mathrm{K}^{+}$channels in hair cells require two to three $\mathrm{Ca}^{2+}$ ions to bind for opening (Hudspeth and Lewis, 1988). If the effect of $\mathrm{ACh}$ involves the positive feedback of $\mathrm{Ca}^{2+}$-triggered release of $\mathrm{Ca}^{2+}$ from an internal store (Shigemoto and Ohmori, 1990), even more thresholdlike behavior might be envisioned, as seen for $\mathrm{Ca}^{2+}$ release in hamster eggs (Igusa and Miyazaki, 1983). Alternatively, the $I_{\mathrm{K}(\mathrm{ACh})}$ channels may themselves be voltage dependent, closing at positive membrane potentials as in renal epithelium (Kolb et al., 1986). It is worth noting that $I_{\mathrm{k}(\mathrm{Ca})}$, activated by flux through voltagegated $\mathrm{Ca}^{2+}$ channels, also is reduced at membrane potentials 
negative to $E_{\mathrm{Ca}}$ in these and other cells (Marty and Neher, 1985; Fuchs et al., 1988).

Identification of the hair cell AChR as related to nicotinic AChRs is supportcd in part by the observation that $\alpha$-bungarotoxin, the specific nicotinic AChR antagonist, blocks the chick hair cell receptor (Fuchs and Murrow, 1991). However, the hair cell AChR does not appear to be identical to the nicotinic AChR since bungarotoxin's effect is readily reversible, nicotine does not activate the receptor, curare and atropine are equipotent antagonists, and strychnine is a potent antagonist (Fuchs and Murrow, 1991; P. A. Fuchs and B. W. Murrow, unpublished observation).

Several studies of efferent inhibitory effects on hair cells provide useful comparisons to the present work. Some of the results obtained in the present experiments are quite similar to those obtained in studies of efferent inhibition in the turtle's cochlea (Art et al., 1982, 1984, 1985). The time course of action of ACh on chick hair cells, and of the efferent transmitter in turtle are reasonably similar given the different methods of delivery. Both rise to a pcak in less than $100 \mathrm{msec}$ and last for several hundred milliseconds (for brief pulses of ACh on chick hair cells, or single efferent action potentials in turtle). The response to ACh desensitizes in both turtle and chick. Further, both the efferent transmitter in turtle and $\mathrm{ACh}$ on chick cells give rise to a biphasic postsynaptic response, an early depolarization, followed by a much larger hyperpolarization that is due to an increase in $\mathrm{K}^{+}$ conductance. Finally, the sensitivity of the chick hair cell AChR to curare, atropine, and TEA is nearly identical to that of the turtle hair cell receptor. Thus, several features of the physiology and pharmacology of the cholinergic response of chick hair cells are identical to those of the turtle hair cell's response to the native efferent transmitter.

A second study was made by Shigemoto and Ohmori (1990), who reported that activation of a muscarinic cholinergic receptor gave rise to $\mathrm{Ca}^{2+}$ release from internal stores in chick cochlear hair cells. In contrast to the present data, this effect did not require $\mathrm{Ca}^{2+}$ influx. The response $\left(\mathrm{a} \mathrm{Ca}^{2+}\right.$ rise measured by a fluorescent dye, fura-2) was elicited by $\mathrm{ACh}$, carbachol, and muscarine and was more sensitive to atropine than to curare. The $\mathrm{Ca}^{2+}$ rise lasted for several minutes. In contrast, in the present study the membrane hyperpolarization and underlying $\mathrm{K}^{+}$currents elicited by $\mathrm{ACh}$ required external $\mathrm{Ca}^{2+}$ and desensitized within seconds. Thus, although superficially similar, in that $\mathrm{Ca}^{2+}$ appears to play the role of a second messenger in both effects of $\mathrm{ACh}$, upon closer examination it seems possible that the earlier study and the present one may in fact be illustrating two different receptor systems on hair cells. One possible explanation for this may lie in the types of cells that were studied. Shigemoto and Ohmori (1990) did not detail what hair cell type they examined; however, their Figure 1 shows a THC, in which cell type we could find no electrical response to ACh. Several authors have suggested that there may be two sources of efferent neurons to the chick's cochlea, one ipsilateral and one contralateral, as in mammals (Whitehead and Morest, 1981). If these distribute differentially to THCs and SHCs, as in mammals (Rebillard and Pujol, 1983), then THCs may in fact be subject to a different type of efferent effect. It will be of some interest to explore this possibility further.

Finally, Housley and Ashmore (1991) have reported that ACh caused mammalian outer hair cells to hyperpolarize by opening $\mathrm{K}^{+}$channels. This response to $\mathrm{ACh}$ was blocked by curare, TEA ions, and strychnine. The effect of ACh also was reduced by prior exposure to $\alpha$-bungarotoxin, which acted as a weak agonist on these cells. The outward current was not produced in $\mathrm{Ca}^{2+}$ free medium, or in the presence of $\mathrm{Cd}^{2+}$. The authors supposed that a $\mathrm{Ca}^{2+}$ influx triggers the outward current but could find no inward current to support that supposition. At least in general terms there appear to be marked similarities between the cholinergic responses of mammalian and avian hair cells.

The experiments reported here have provided direct evidence that a $\mathrm{Ca}^{2+}$ influx is necessary for the ACh reponse. This influx presumably occurs through nonspecific cation channels formed by the hair cell AChR. In muscle the nicotinic AChR also forms a cation channel, and $\mathrm{Ca}^{2+}$ ions carry approximately $2 \%$ of the charge flowing through that channel under physiological conditions (Decker and Dani, 1990). If the hair cell AChR has a similar selectivity (as suggested by reversal of its current near $0 \mathrm{mV}$ ), then a very small influx of $\mathrm{Ca}^{2+}$ appears capable of triggering the much larger $\mathrm{K}^{+}$currents seen in these recordings. The average conductance increase due to the late $\mathrm{K}^{+}$current was almost 10 times larger than the average conductance increase due to the early inward current alone $(7.6 \mathrm{nS}$ compared to $0.8 \mathrm{nS}$ ). This makes the results with intracellular BAPTA especially interesting. Since $5 \mathrm{~mm}$ BAPTA, but not $11 \mathrm{~mm}$ EGTA, was capable of preventing the action of $\mathrm{Ca}^{2+}$ in the hair cell ACh response, this implies that a very rapid, tightly buffered, and closely localized effect of $\mathrm{Ca}^{2+}$ is involved. That is, BAPTA's superiority in this regard is probably a consequence of its more rapid binding kinetic with $\mathrm{Ca}^{2+}$ (Adler et al., 1991). This conclusion is also supported by the observation that it is possible to record ACh responses in dialyzed hair cells for up to an hour, ruling out freely diffusible intermediates in the reaction chain.

These observations also suggest that the ACh-elicited $\mathrm{K}^{+}$ channels must be very near the site of $\mathrm{Ca}^{2+}$ action, perhaps colocalized with the AChRs. This is reminiscent of the colocalization of $\mathrm{Ca}^{2+}$-activated $\mathrm{K}^{+}$channels and voltage-gated $\mathrm{Ca}^{2+}$ channels in frog saccular hair cells (Roberts et al., 1990). At the same time, this and other observations suggest that the $\mathrm{ACh}$ activated $\mathrm{K}^{+}$channels are probably not the "maxi" $\mathrm{K}^{+}$channels that are activated by influx through voltage-gated $\mathrm{Ca}^{2+}$ channels in these same hair cells, although both are $\mathrm{Ca}^{2+}$ dependent. The evidence for this is that internal $\mathrm{Cs}^{+}$ions block $I_{\mathrm{K}(\mathrm{Ca})}$ (Fuchs and Evans, 1990) but do not block $I_{\mathrm{K}(\mathrm{ACh})}$. Also, evocation of the ACh-evoked $\mathrm{K}^{+}$currents caused almost no increase in current noise over background, while "maxi" $\mathrm{K}^{+}$currents of similar magnitude and at the same membrane potentials produce a substantial increase in current variance (Fuchs and Evans, 1990). This suggests that the ACh-evoked $\mathrm{K}^{+}$currents flow through much smaller channels than those carrying $I_{\mathrm{K}(\mathrm{Ca})}$. Finally, the $I / V$ relation of $I_{\mathrm{K}(\mathrm{Ca})}$ is sharply rectified about the reversal potential (Fuchs and Evans, 1990), while that of $I_{\mathrm{K}(\mathrm{ACh})}$ was much less so.

In addition to being carried by different channels, $I_{\mathrm{K}(\mathrm{ACh})}$ and $I_{\mathrm{K}(\mathrm{Ca})}$ are spatially segregated as well. For example, they appear not to be co-activated. Influx of $\mathrm{Ca}^{2+}$ through voltage-gated $\mathrm{Ca}^{2+}$ channels activates the very rapid $I_{\mathrm{K}(\mathrm{Ca})}$ (Fuchs and Evans, 1990), but no additional slower, long-lasting $\mathrm{Ca}^{2+}$-dependent component, as would be expected if $I_{\mathrm{K}(\mathrm{ACC})}$ were activated. Likewise, if ACh activated $I_{\mathrm{K}(\mathrm{Ca})}$ one would expect a contribution to current noise from this large channel. Finally, most SHCs had many times morc $I_{\mathrm{K}(\mathrm{ACh})}$ than $I_{\mathrm{K}(\mathrm{Ca})}$. From these considerations one can conclude that the channels carrying these two $\mathrm{K}^{+}$currents are different molecular entities whose synthesis and membrane insertion must be differentially regulated, and that they may be 
colocalized with their own inward current channels: voltagegated $\mathrm{Ca}^{2+}$ channels for $I_{\mathrm{K}(\mathrm{Ca})}$, cationic AChRs for $I_{\mathrm{K}(\mathrm{ACh})}$.

The hair cell cholinergic response appears to be served by a high degree of synaptic specialization, at a minimum including the colocalization of two specific membrane proteins, the hair cell AChR and the associated $\mathrm{K}^{+}$channels, in keeping with the simplest adequate interpretation adopted in this article. However, ultrastructural studies show that the postsynaptic specialization may be considerably more elaborate than this. The efferent endings are coextensive with a "subsynaptic cistern" in the hair cell (Hirokawa, 1978; Tanaka and Smith, 1978). Shigemoto and Ohmori (1990) found that $\mathrm{ACh}$ could cause release of $\mathrm{Ca}^{2+}$ from internal stores (albeit over a much longer time course), and our data might be considered in terms of a more complex model including $\mathrm{Ca}^{2+}$-triggered release of $\mathrm{Ca}^{2+}$ from just such an internal store as the subsynaptic cistern, as in excitation-contraction coupling in heart muscle (reviewed by Fabiato, 1983). Whatever mechanism obtains, the voltage dependence of $I_{\mathrm{K}(\mathrm{ACh})}$ requires that it must rely on some ionic influx, presumably that of $\mathrm{Ca}^{2+}$ itself.

\section{References}

Adler EM, Augustine GJ, Duffy SN, Charlton MP (1991) Alien intracellular calcium chelators attenuate neurotransmitter release at the squid giant synapse. J Ncurophysiol 11:1496-1507.

Art JJ, Fettiplace R (1987) Variation of membrane properties in hair cells isolated from the turtle cochlea. J Physiol (Lond) 385:207-242.

Art JJ, Crawford AC, Fettiplace R, Fuchs PA (1982) Efferent regulation of hair cells in the turtle cochlea. Proc R Soc Lond [Biol] 216:377384.

Art JJ, Fettiplace R, Fuchs PA (1984) Synaptic hyperpolarization and inhibition of turtle cochlear hair cells. J Physiol (Lond) 356:525-550.

Art JJ, Crawford AC, Fettiplace R, Fuchs PA (1985) Efferent modulation of hair cell tuning in the cochlea of the turtle. J Physiol (Lond) $360: 397-421$.

Dale HH (1914) The action of certain esters and ethers of choline, and their relation to muscarine. J Pharmacol Exp Ther 6:147-190.

Decker ER, Dani JA (1990) Calcium permeability of the nicotinic acetylcholine receptor: the single channel calcium influx is significant. J Neurosci 10:3413-3420.

Fabiato A (1983) Calcium-induced release of calcium from the cardiac sarcoplasmic reticulum. Am J Physiol 245:Cl-C14.

Fex J (1962) Auditory activity in centrifugal and centripetal cochlear fibres in cat. A study of a feedback system. Acta Physiol Scand 55[suppl 189]:1-68.

Fex J, Adams JC (1978) $\alpha$-Bungarotoxin blocks reversibly cholinergic inhibition in the cochlea. Brain Res 159:440-444.

Firbas W, Muller G (1983) The efferent innervation of the avian cochlea. Hear Res 10:109-116.

Fuchs PA, Evans MG (1988) Voltage oscillations and ionic conductances in hair cells isolated from the alligator cochlea. J Comp Physiol A 164:151-163.

Fuchs PA, Evans MG (1990) Potassium currents in hair cells isolated from the cochlea of the chick. J Physiol (Lond) 429:529-551.
Fuchs PA, Murrow BW (1991) Inhibition of cochlear hair cells by acetylcholine. J Gen Physiol 98:28a.

Fuchs PA, Nagai T, Evans MG (1988) Electrical tuning in hair cells isolated from the chick cochlea. J Neurosci 8:2460-2467.

Fuchs PA, Evans MG, Murrow BW (1990) Calcium currents in hair cells isolated from the cochlea of the chick. J Physiol (Lond) 429: 553-568.

Galambos R (1956) Suppression of auditory nerve activity by stimulation of efferent fibers to the cochlea. J Neurophysiol 19:424-437.

Hirokawa $N$ (1978) The ultrastructure of the basilar papilla of the chick. J Comp Neurol 181:361-374.

Housley GD, Ashmore JF (1991) Direct measurement of the action of acetylcholine on isolated outer hair cells of the guinea pig cochlea. Proc R Soc Lond [Biol] 244:161-167.

Hudspeth AJ, Lewis RS (1988) Kinetic analysis of voltage- and iondependent conductances in saccular hair cells of the bull-frog, Rana catesbeiana. J Physiol (Lond) 400:237-274.

Igusa I, Miyazaki S (1983) Effects of altered extracellular and intracellular calcium concentration on hyperpolarizing responses of the hamster egg. J Physiol (Lond) 340:61 1-632.

Klinke R (1981) Neurotransmitters in the cochlea and the cochlear nucleus. Acta Otolaryngol (Stockh) 91:541-554.

Kolb HA, Brown CDA, Murer $\mathrm{H}$ (1986) Characterization of a $\mathrm{Ca}^{++}$. dependent maxi $\mathrm{K}^{+}$channel in the apical membrane of a cultured renal epithelium (JTC-12.P3). J Membr Biol 92:207-215.

Lewis RS, Hudspeth AJ (1983) Voltage and ion-dependent conductances in solitary vertebrate hair cells. Nature 304:538-541.

Marty A, Neher E (1985) Potassium channels in cultured bovine adrenal chromaffin cells. J Physiol (Lond) 367:117-141.

Murrow BW, Fuchs PA (1990a) Preferential expression of transient potassium current $\left(I_{\mathrm{A}}\right)$ by 'short' hair cells of the chick's cochlea. Proc R Soc Lond [Biol] 242:189-195.

Murrow BW, Fuchs PA (1990b) Short (outer) hair cells of the chick's cochlea are hyperpolarized by carbachol. Soc Neurosci Abstr 16:1079.

Ohmori H (1984) Studies of ionic currents in the isolated vestibular hair cell of the chick. J Physiol (Lond) 350:561-581.

Rebillard M, Pujol R (1983) Innervation of the chicken basilar papilla during its development. Acta Otolaryngol (Stockh) 96:379-388.

Roberts WM, Jacobs RA, Hudspeth AJ (1990) Colocalization of ion channels involved in frequency selectivity and synaptic transmission at presynaptic active zones of hair cells. J Neurosci 10:3664-3684.

Shigemoto $\mathrm{T}$, Ohmori $\mathrm{H}$ (1990) Muscarinic agonists and ATP increase the intracellular $\mathrm{Ca}^{2+}$ concentration in chick cochlear hair cells. $\mathrm{J}$ Physiol (Lond) 420:127-148.

Takasaka T, Smith CA (1971) The structure and innervation of the pigeon's basilar papilla. Ultrastruct Res 35:20-65.

Tanaka K, Smith CA (1978) Structure of the chicken's inner ear: SEM and TEM study. Am J Anat 153:251-272.

Tsien R (1980) New calcium indicators and buffers with high selectivity against magnesium and protons: design, synthesis, and properties of prototype structures. Biochemistry 19:2396-2404.

Whitehead MC, Morest DK (1981) Dual populations of efferent and afferent cochlear axons in the chicken. Neuroscience 6:2351-2365.

Wong LA, Gallagher JP (1991) Pharmacology of nicotinic receptormediated inhibition in rat dorsolateral scptal ncuroncs. J Physiol (Lond) 436:325-346. 